ARTICLE

\title{
Presentist History for Pluralist Science
}

\author{
Hasok Chang ${ }^{1}$ \\ Published online: 2 June 2020 \\ (C) The Author(s) 2020
}

\begin{abstract}
Building on my previous writings on presentism, pluralism, and "complementary science", I develop an activist view of historiography. I begin by recognizing the inevitability of presentism. Our own purposes and perspectives do and should guide the production of our accounts of the past; like funerals, history-writing is for the living. There are different kinds of presentist history, depending on the historians' purposes and perspectives. My particular inclination is pluralist. Science remembers its own history from a particular perspective ("whiggism"), which views the past as imperfect versions of the present; if professional historians of science shared this perspective, our work would be redundant. Instead, we can make it our task to illuminate the aspects of the past of science that scientists themselves tend to ignore and forget. History of science can also take a more productive role in the creation and improvement of scientific knowledge. Scientific progress as we know it tends to involve the shutting down of alternative paths of inquiry, resulting in a loss of potential and actual knowledge. A critical and sympathetic engagement with the past allows us to recover the lost paths, which can also suggest new paths. These points will be illustrated by a number of examples, especially from the history of chemistry and physics, including the recovery and extension of past experiments.
\end{abstract}

Keywords Pluralism $\cdot$ Presentism $\cdot$ Whiggism $\cdot$ Complementary science $\cdot$ Experimental replications

\section{Introduction}

In this paper I seek to synthesize and develop my previously expressed views on three topics: presentism in history-writing, pluralism in science, and the "complementary" role of history and philosophy of science with respect to specialist science. The synthetic position may be considered a particular type of activist historiography, which holds that by writing history we should attempt to achieve specific aims pertinent to other aspects of human life, going beyond a mere description of the past. In short, my position is that presentism is inevitable in history-writing, but that there is a choice to be made in what kind of

Hasok Chang

hc372@cam.ac.uk

1 Department of History and Philosophy of Science, University of Cambridge, Free School Lane, Cambridge CB2 3RH, UK 
presentism we opt for; my preference is for a pluralist presentism, which seeks to recover and develop aspects of past science that tend to be ignored in scientists' own views of the past. There are many elements going into this synthesis; some of them were developed in detail in previous publications, and will only be summarized very briefly; others were insufficiently developed before, and will receive more detailed attention here.

\section{The Inevitability of Presentism}

\subsection{Is Anti-presentism in the Historian's DNA?}

Presentism in historiography is inevitable in a basic sense: the historian is quite simply stuck in the present, and it does not make sense to attempt to escape the present (Chang 2009, 252). This point deserves revisiting and reinforcing, especially since presentism remains an anathema to most enlightened historians of science, and perhaps to good historians in general. In the memorable words of Herbert Butterfield, who gave us the derogatory notion of "Whig history" $(1931,32)$ : "The study of the past with one eye, so to speak, upon the present is the source of all sins and sophistries in history, starting with the simplest of them, the anachronism." "1 Michael Gordin, in his review of my book Is Water $\mathrm{H}_{2} \mathrm{O}$ ? (Chang 2012a) affirms that Butterfield's words have become solidified as common sense among today's historians of science: "there is no surer way to dismiss an article, monograph, or talk in the history of science than to expose the Whiggish elements of its analysis." And he thinks that historians of science are more sensitive to this issue than other historians: "In some ways, a militant hostility to Whiggish narratives defines the history of science against other fields, and one can often spot historians of science at a talk when they query the potentially Whiggish approach of a speaker in, say, military or legal or political history." (Gordin 2014, 417; emphasis original) Gordin considers that "Anti-Whiggism seems mandatory today because we have wired it into the central core of our field as a discipline." (Gordin 2014, 420, emphasis original)

We have certainly come a long way from 50 years ago, when Thomas Kuhn advocated the "new internal historiography of science", which he characterized as follows: "Insofar as possible... the historian should set aside the science that he knows. His science should be learned from the textbooks and journals of the period he studies... Dealing with innovators, the historian should try to think as they did.... the historian should ask what his subject thought he had discovered and what he took the basis of that discovery to be." (Kuhn [1968] 1977, 110) Gordin's summary of the ideal of anti-Whiggism is very much along the same lines: "treating the past on its own terms as much as possible, and not simply as a runway aimed at the present" (Gordin 2014, 421-422).

\subsection{We Cannot Get Away from Ourselves}

I want to argue against this disciplinary common sense. Let me begin with a dilemma. At the core of historians' aversion to presentism is the fear of getting the past wrong, the worry that writing history "with one eye upon the present" will introduce distortions and

\footnotetext{
1 See Wilson and Ashplant $(1988,15)$ for a succinct view of the problems of presentism, or rather presentcenteredness.
} 
falsehoods in our view of the past. But the very notion of unqualified objective truth is something that anti-Whiggish and anti-presentist historians of science have done so much to discredit, so it feels at least uncomfortable for anti-presentism then to invoke plain truth in its own defence. But if we come away from the talk of unqualified truth, then in being anti-Whiggish, or anti-presentist more generally, we are declaring that a certain type of perspective on the past is bad. This requires justification. Butterfield maintained that "real historical understanding" was achieved through "attempting to see life with the eyes of another century than our own" $(1931,16)$, but we need to ask if that is really the only way or even the best way to achieve historical understanding.

Now, let me come to the sense in which presentism is plainly valid and quite inescapable: we historians are inevitably living in the present, no matter how much we might kick and scream about it. The historian's present self cannot be removed from the process or the product of history-writing. Our own purposes and perspectives must guide the production of our accounts of the past, as they guide the production of anything else that we might say and understand. Laurent Loison notes a "resurgence of presentism in the field of history of science" in recent years, and goes as far as to say: "The question is therefore no longer if we have to make room for presentism, but rather how we should use presentism." (Loison 2016, 29; emphases original) And this is not just his own personal view, but a summing-up based on a careful and comprehensive digest of recent literature. ${ }^{2}$

Even though history is about the past, history-writing is for those who are living in the present. This is a trivial point, but a clear affirmation of the trivial is a good starting point. Let me propose a presentist slogan: "Like funerals, history-writing is for the living." 3 There are actually two different points here, which I should distinguish carefully if I am to get beyond mere sloganeering. The first point is that it is not plausible to set aside our present perspectives completely. Even if you could climb into Aristotle's head, as Kuhn was fond of recommending, how would you know how to navigate inside it? And if you somehow really succeed in thinking and talking just like Aristotle and his contemporaries, how would you come back and tell the rest of us what you have learned? ${ }^{4}$ If you could truly attain this ideal of historiography, you would be Aristotle, and we would need other historians to decipher for the rest of us what you are saying. The completely faithful history, if one could achieve it, might just be the past itself, like Borges's perfect map that is just the terrain itself, and therefore completely useless.

There is an ironic way to put this point. Butterfield targeted anachronism as the "simplest" of all historical sins, but the word has two different definitions: "1. the representation of an event, person, or thing in a historical context in which it could not have occurred or existed; 2. a person or thing that belongs or seems to belong to another time." 5 So, if we truly succeeded in avoiding anachronism (def. 1), then we would become an anachronism (def. 2). Anachronism can be both the imposition of the present onto the past, and the unwanted intrusion of the unfiltered and incomprehensible past into the present! There are insurmountable problems with the idea that the historian should simply give a complete and accurate description of the past and reach a faithful understanding of the past. I do not

\footnotetext{
${ }^{2}$ I do not cite here all the works discussed in Loison's excellent article, but merely refer the reader to his bibliography and his succinct presentation of various key sources.

3 The saying about funerals being for the living is attributed to Roelif Coe Brinkerhoff.

${ }^{4}$ Loison $(2016,31)$ takes the need to communicate in the present as the basis for what he calls "descriptive presentism".

5 Collins English Dictionary, 4th ed. (1998).
} 
at all mean to deny that the past is "a foreign country" where "they do things differently". But when we travel to that foreign country we remain to a significant extent who we are, and "going native" can only be partial if we hope to tell anyone else what we learn by doing so.

Now, there is an obvious rejoinder to this, from the opponents of presentism: we historians cannot get completely away from the present, but we should try. Here is Gordin again (2014, 421): "The most important quality of Tory [anti-Whig] history is that it is hard, even unnaturally hard." Agreed-but how do we deal with that difficulty? This brings me to the second sense in which history-writing is for the living. Given that it is impossible to rid ourselves of the present completely, there are choices to be made, regarding how much and which specific parts of our present selves we should try to set aside, and which other parts we should accept as the platform for our narrative and analysis. These choices should be made according to the purposes of the various people who produce and utilize accounts of the past. So we come to the big question of historiography: why do we do history? - which is also to say-why do we do history? It is absurd to imagine that we can have a full sense of what is good and bad history, if we have not carefully articulated the purposes of doing history. Sadly, I have often observed colleagues and students passing such judgements in the absence of articulated purposes.

In contrast, Butterfield himself emphasized that the description of any historical situation was inevitably a matter of "abridgement" (Butterfield 1931, 24, etc.). The process of abridgement is unavoidably guided by our conceptual frameworks and our interests. When we move beyond mere description and think about the explanatory tasks of the historian, it is even more apparent that we cannot take the historian out of the history. What counts as a satisfactory explanation is surely dependent on our broader assumptions and aspirations. ${ }^{6}$ In addition, just as we historians do not want to let scientists believe that their selection of problems to study is completely disinterested, we should not let ourselves believe that our selection of historical questions is not affected by our present concerns. Accepting these aspects of subjectivity or "perspectivality" in the work of the historian means accepting present-centeredness.

All this, on reflection, is hopefully a matter of common sense for anyone who has actually done historical research and writing. But why might it come across as controversial? As Nick Jardine once said (2003, 134): "All too often recent historians of science have abandoned common sense in their flight from presentism." Jardine himself has a more relaxed view about presentism, and considers that the interpretation of the past in terms of the present is indispensable to the work of the historian (Jardine 2003, 128).

\subsection{Activist Presentism}

The sense of presentism just discussed indicates that the inevitability of presentism is not the end of the story. We can also think more positively about how to embrace the inevitable presence of the present, using it selectively and wisely in order to do better history to meet our historiographical purposes. That is the activist meaning that I would like to give to the word "presentism": it is an "ism" in the sense of an ideology, a commitment to investigate history based on a clear and conscious engagement with our present, ultimately in order to

\footnotetext{
6 This is on full display in a recent "Focus" section of the journal Isis, which was a collection of exemplary explanatory accounts provided by leading historians of science (Cohen, ed., 2019).
} 
improve that present. I have quoted Paul Forman more than once in this connection (Chang $2009,254 ; 2017,104)$, but it is worth highlighting again his inspiring exhortation for historians of science to embrace "the obligation to decide for ourselves what is the good of science, and by our historical research and writing to advance that good." (Forman 1991, 86) At the centre of Forman's vision is the historian as a free and active agent, firmly and consciously rooted in her or his own present. A judicious and active presentism can be an effective aid to historiography.

One particular issue that deserves close attention is the often-repeated anti-presentist advice that we should always seek to use actors' categories in our historical descriptions and analyses. For the purpose of reaching the most informative and meaningful description or explanation, there is actually no guarantee, not even a very high likelihood, that actors' categories provide the best framework for it. ${ }^{7}$ The very designation of our business as the "history of science" constitutes a general admission of this point, if we include the pre-modern branches of learning (in Europe and even the rest of the world) as part of our subject matter. And I think there is indeed a case for including at least certain aspects of alchemy and astrology, for example, in the history of science. Many would bristle at calling a 16th-century alchemist a "scientist", but before we give a purist reaction we should think carefully about exactly what harm such a designation does. I think it actually does more good than harm to regard an alchemist as a scientist, at least as a refreshing alternative to the more usual conception of an alchemist as a mystic or an occultist. Of course, the benefit or harm of such designations depends on the context in which we are working. But that is exactly the nature of the kind of presentism that I am advocating: what counts as a cogent and informative historical description depends on the historian's own present context.

When it comes to explaining the past, the possible benefits of departing from the actors' own conceptions are even more evident. ${ }^{8}$ For example, a Marxist analysis of the political and cultural practices of a society in terms of the modes of economic production can be very informative and illuminating even if the "mode of production" would have been an entirely alien concept to the people of that society themselves. And even if the actors did possess the conceptual categories in terms of which we historians are trying to understand their actions, it may well be the case that they would have sincerely denied the cogency of the explanations offered by us. One does not have to look very far to find people that we think were clearly motivated by racist, sexist, imperialist and other motivations, to whom such explanations would have come as a genuine surprise. Similarly, when Mario Biagioli (1993) says that Galileo's actions make the best sense when we understand them as calculated to attain maximal patronage from the Medici court, or when Steven Shapin (1975) says that the advocates of phrenology in early 19th-century Edinburgh were motivated by social interests, or when Paul Forman (1971) says that physicists and mathematicians were prematurely pushed into renouncing causality in physics by capitulating to the cultural pressures of the Weimar era, we can accept those historical explanations as cogent and insightful, regardless of whether the actors themselves would have seen such explanations as correct or even coherent. Understanding what the actors themselves thought is valuable, but it is not necessarily the best way of understanding why they thought or did what they did.

\footnotetext{
7 For a similar conclusion see Arabatzis (2019, 357-358), in his masterful summing-up commentary on the Focus section of the Isis issue mentioned in the previous note.

8 This is related to what Loison $(2016,31-32)$ calls "causal-narrative presentism".
} 
What matters ultimately is not whether to restore supremacy to the past actors' own description of themselves and their own times, but how to manage different parties in the present with different interests and opinions fighting it out for the right to offer their views of the past. That is a very important point for the practice of revisionism, a staple in the work of thoughtful historians. Revisionism is, by definition, an activity shaped by the present, namely the present state of historiography. It would be very difficult to argue that what counts as a cogent and useful revision is independent of our own positions. In revisionist history we can certainly do a better job by being more aware of our present selves. But it is also a general theme in any historiography: a more conscious presentism should beneficially enhance our awareness of the present factors that inevitably enter our historical work.

\section{Different Kinds of Presentism}

Having argued for presentist historiography in general terms, I now want to distinguish different kinds of presentism and consider their merits and demerits, before I articulate in the next section the particular kind of presentism that I advocate. There are many possible varieties of presentism. Loison (2016) helpfully distinguishes four different common forms of it, plus one other that he himself advocates, building on Georges Canguilhem's historical epistemology. Although I have not framed my whole analysis in terms of Loison's typology, in the course of my discussion I refer to various types distinguished by him whenever it is illuminating to do so. From my own perspective, I want to highlight three manifestations of presentism for consideration here, because they tend not to receive proper attention in the literature.

\subsection{Whiggism}

The first is whiggism. ${ }^{9}$ Presentism is not synonymous with whiggism, despite the frequent conflation of the two. Whiggism is only one particular variety of presentism, based on a strong optimistic assumption of progress that conceives present science to be unequivocally better than past science. Even though it is a widespread assumption among those who think seriously about science, it is not shared by all presentists. It is a real possibility, for example, to regard the history of science as a succession of different ways of understanding nature, none clearly better than the rest (consider Paul Feyerabend's views, for example).

I do not expect readers of this paper to be surprised to hear that there are problems with whiggism. Rather than rehearsing the well-known problems, I want to put forward a complementary point: even whiggism has its uses. Let us consider whether there are any merits to whiggism, or rather, any circumstances under which whiggism serves a useful function. The prevalence of whiggish history of science cannot be explained simply as a result of people's ignorance or crudeness; rather, whiggism is so prevalent because it does serve some useful functions. Whiggish history motivates aspiring science students, and reminds

\footnotetext{
${ }^{9}$ From this point on in the paper I will use the words "whiggism" and "whiggish" without capitalizing it, to indicate that it is a general historiographical position that is meant, rather than a specific reference to the Whig Party in English (or American) history.
} 
the public of the virtues of science. These are significant and noble purposes, though they should not be pursued dogmatically and in a way that encourages false consciousness.

Whiggism can also serve a surprising revisionist function. This is when it meets something even more crude, namely what I have called "triumphalism" (Chang 2009, Sect. 4), which takes the side of whoever was the winner in an argument or a struggle. A very simple and simple-minded example will illustrate this point. In the city of Leeds in northern England there is a small church called Mill Hill Chapel, which proudly displays a commemorative blue plaque outside: "Joseph Priestley, LL.D., F.R.S., discoverer of oxygen, was minister here 1767-1773." This declaration might make both Priestley and Lavoisier turn in their graves. Lavoisier: no, I discovered oxygen! Priestley: I discovered no such thing-I discovered dephlogisticated air! The impulse on the part of those who say that Priestley discovered oxygen is quite clearly whiggish. They dispense with Priestley's own categories, in order to fit him into the progressive march of science: he made that gas which was later recognized as oxygen, and did so before Lavoisier, so let us not be fussy about it and just call Priestley the discoverer of oxygen. In normal circumstances such a simplification would be a somewhat pointless distortion of history, but in this case it serves as a useful corrective to the tendency to give all the credit to the victorious Lavoisier.

Therefore, to call Priestley the discoverer of oxygen can be a very useful and instructive thing because it makes people think differently. And it is more effective in this regard than emphasizing that Priestley discovered dephlogisticated air, to which the typical uninformed response would be "So what?" Although there are some situations in which it is better not to translate "dephlogisticated air" into "oxygen", that is not universally the case. I came across Priestley's blue plaque in the midst of my research challenging the still surprisingly widespread narrative that Lavoisier was the "father of modern chemistry" and that the discovery of oxygen was the centrepiece of his Chemical Revolution. In this context it was very useful to have a reminder that it was Priestley the recalcitrant phlogistonist who actually discovered oxygen and told Lavoisier about it in the first place. ${ }^{10}$ That never fails to make the naïve scientific or public audiences to sit up and pay attention.

\subsection{Philosophical History}

The second mode of presentism that I want to highlight is a common and conscious use of the history of science by philosophers of science. This is the business of trying to characterize the nature of scientific knowledge and its development, using historical facts as evidence for or against various philosophical views. What is presentist about history done for such a purpose is, of course, the fact that most philosophers are using current philosophical conceptions, rather than those belonging to the settings in which the past scientists in question operated. And this should be separated from the incidental fact that most philosophers also happen to be whiggish about the history of science; it is by no means necessary for philosophy to be whiggish, as it is not a requirement that philosophers should subscribe to progressivism.

Historians of science observing the typical philosophers' use of history often get quite irritated: on the one hand, they do like attention being paid to history, and empirically

\footnotetext{
10 And Carl Wilhelm Scheele, another phlogistonist, actually made oxygen even before Priestley, though the publication of his work was unfortunately delayed. Recognizing the plurality of answers is more useful than going into a blind realism (but who, really, discovered oxygen?), or nihilism ("discovery" means nothing).
} 
grounded arguments are preferable to pure armchair philosophy; on the other hand, philosophers engaged in this exercise often seem to misuse history. There has been a clear allergic reaction against the "historical philosophy of science", and this has constituted a serious obstacle in the way of establishing history-and-philosophy of science as an integrated discipline. ${ }^{11}$ One emblematic moment in this debate was the opposition between Thomas Kuhn and Imre Lakatos, who clashed at the Philosophy of Science Association conference in 1970. Objecting especially to Lakatos's notion of "rational reconstruction of history", ${ }^{2}$ Kuhn retorted (1971, 143): "What Lakatos conceives as history is not history at all but philosophy fabricating examples.... Why is it... that Lakatos feels the need to protect himself from real history?" He continued his attack a decade later (Kuhn 1980, 182-183): Lakatosian historians "aim to show that much scientific behavior, previously seen as anomalous or irrational, demanding of external historical explanation, appears appropriate and rational when viewed in terms of Lakatos's method of research programmes. As a motive for doing history that one seems to me a likely invitation to disaster."13

The historians' wariness here is understandable. However, it is a mistake to think that philosophical framing of history, in comparison to other types of framing, has a particularly distorting effect on the facts. Rather, what is often problematic is a particular manner of philosophical framing that is based on a simplistic view of the philosophy-history relation as a version of the naively conceived theory-evidence relation. It may work to consider the philosophy of science as "the science of science", but not if it is modelled on an outdated view of how empirical science works. Lakatos (1971) was very well aware of the pitfalls here, and gave a lengthy discussion of how the philosophy of science provides meta-level research programmes in the historiography of science.

The legitimacy of present philosophical concepts as framing devices for historiography, in general, requires no justification over and above the general justification for presentism in Section 2. Whatever concern that is important to us in the present should be allowed a role as a framing device for historiography, and philosophical concerns are no exception. Almost any conceptual framework can serve as a vehicle for historical investigation, and ultimately its usefulness can only be judged by its fruits. It is a legitimate way of doing history, to ask whether and how actual scientific developments fit with certain philosophical views about how science works, whether they be realism, reductionism, Bayesian evidential reasoning, or whatever. We can ask whether and how scientific practices have embodied certain values, such as simplicity, scope, or explanatory power. We can also ask about the ethical stances and struggles of past scientists. Or we can trace in scientific practices certain metaphysical doctrines concerning causation, identity, space and time, or whatnot. These philosophical questions concerning science are just as valid and interesting as sociological, political, cultural, economic, or other kinds of questions. Their value and cogency depend on the contexts and the conduct of investigation. There should not be a blanket prohibition of the philosophical framing of historical questions.

\footnotetext{
11 For a detailed discussion of this tension, see Chang (2012b) and references therein, including Kuhn's 1968 paper on "the trouble with the historical philosophy of science".

12 Witness the infamous suggestion from Lakatos (1971, 107; emphases original): "One way to indicate discrepancies between history and its rational reconstruction is to relate the internal history in the text, and indicate in the footnotes how actual history 'misbehaved' in the light of its rational reconstruction."

13 Conscious of his own notorious view that facts are not neutral arbiters of theory, Kuhn added: "The historian's problem is not simply that the facts do not speak for themselves but that, unlike the scientist's data, they speak exceedingly softly. Quiet is required if they are to be heard at all."
} 
The defence of philosophical history can be made stronger and sharper, too. If history of science should concern itself chiefly with the development of scientific knowledge, then we might argue that epistemology is the most proper framework for the historiography of science, after all. And if we should take a broader view of what philosophy means, we can endorse Ernest Gellner's view on the necessity of philosophical history (1988, 11-12): "We inevitably assume a pattern of human history. There is simply no choice concerning whether we use such a pattern. We are, all of us, philosophical historians malgré nous, whether we wish it or not. The only choice we have is whether we make our vision as explicit, coherent and compatible with available facts as we can, or whether we employ it more or less unconsciously and incoherently.... Those who spurn philosophical history are slaves of defunct thinkers and unexamined theories."

\subsection{Emancipatory Presentism}

The mode of presentist history I next want to examine engages with the past in quite a different way. In what I will call "emancipatory" historiography, the historian uses the understanding of the past to liberate us from its legacy. If we recognize that contingent decisions made in the past shape our present, we can see that what may seem inevitable to us actually was, and can again be, a matter of human choice. This rather psychoanalytic insight is perhaps not a mainstream view in historiography, but it has a very respectable pedigree, including Johann Wolfgang von Goethe, Wilhelm Dilthey, and Benedetto Croce. It was Croce $(1941,48)$ who gave us the famous dictum: "Only historical judgement liberates the spirit from the pressure of the past."

This insight is perhaps most obviously applicable in political history, but I believe that our scientific life, too, can benefit from seeing the apparent necessities of today as consequences of past contingencies. Where I first came across Croce's dictum was in the physicist John Archibald Wheeler's preface to the summary volume for the Archive for the History of Quantum Physics (Kuhn et al. 1967, v). Wheeler did not elaborate on what kind of liberation concerning quantum physics one could seek from understanding its history, but I think that a key issue informing his thinking must have been the historical contingency involved in the establishment of the Copenhagen Interpretation. Wheeler is known for his advocacy of the unorthodox "many-worlds interpretation" of quantum mechanics, which was his particular gloss on the work of Hugh Everett. This counter-orthodox historiographical vision concerning quantum physics is expressed more clearly and explicitly in works by James Cushing (1994) and John Heilbron (1985). ${ }^{14}$

I have enormous appreciation for emancipatory historiography. A large part of my own research has been carried out in its spirit, exposing the historical contingency of many items of scientific common sense, ranging from the belief that water is $\mathrm{H}_{2} \mathrm{O}$ (Chang 2012a) to the necessary truth of the standard interpretation of the special theory of relativity (Chang 1993). However, I think there is a limitation to emancipatory presentism in that it is only reactive, responding to specific undesirable legacies of the past. This is similar to how the news cycle easily gets dominated by unsavory persons and happenings, rather than more positive matters. It is possible for presentist history to claim a broader and

\footnotetext{
14 There are similar examples concerning other areas of physics, including Andrew Pickering's (1984) work showing contingency in the establishment of quantum chromodynamics.
} 
independent remit, starting from the most important of our present concerns and seeking out the historical roots of the pertinent elements of our present situation.

\section{Pluralist Presentism}

\subsection{Pluralism, Anti-whiggism and the Point of Professional History}

I hope I have said enough by now to demonstrate that a basic level of presentism is unavoidable in our work as historians, and that adopting various types of presentism consciously and deliberately can enhance the value of our historical work. Now I would like to articulate my own particular view on how best to shape and direct presentist historiography. Of the many purposes that we can achieve by doing history, which do I particularly aim for, and how? I advocate a historiographical pluralism, which works in close relation to pluralism concerning science itself. I believe that the most urgent task of history-writing is to offer perspectives on the past that are missing in mainstream views. This is still presentism, but of a rebellious kind. It stems from the recognition that the present is not one monolithic entity, even in science. There are various actors and various perspectives and various interests in our present social and scientific world. Historiographical pluralism is a commitment to recognize this plurality, and to resist the exclusive commandeering of the past by the dominant forces of today. Such pluralism is in fact a very familiar and accepted historiographical trend in our postmodern world of identity politics. But does it have any validity concerning the history of science? My answer is yes.

My view is based on a pluralism concerning scientific knowledge itself, which I have argued for elsewhere (especially Chang 2012a, ch. 5). I will not repeat those arguments here; instead I want to discuss what good historiography of science should look like, if we accept pluralism about science- - which is also to say, how pluralism about science leads to pluralism in the history of science. Before I go on, I should briefly state what I conceive pluralism concerning science to be: it is a commitment to maintain and develop multiple systems of practice even within a given field of study. The need for such pluralism concerning science arises from the fact that modern science has developed largely in a monist spirit-looking for the one scientific truth about the one reality that we all inhabit, assuming that there is one right answer to each scientific question, and one best method for arriving at that right answer.

This monistic, even dogmatic, nature of modern science has a clear effect on scientists' perspectives on the past. History of science written by monist scientists tends to downplay the plurality that has existed in science, reinforcing the impression that successful science always requires uniformity and consensus. Given this situation, it makes sense for professional historians of science to become pluralists, to illuminate the parts of the past of science that scientists themselves ignore. Pluralist historians turn away from the celebration of the winners, and even from the usual search for consensus-points. We seek to counter the retrospective tidying-up tendency of other historians and most scientists, freely exhibiting long-running disputes and unresolved questions and celebrating the rugged individualists and quirky sub-communities.

Such pluralism gives us a useful perspective from which to re-examine whiggism, which now seems more clearly a redundant and futile sort of historiography, if practiced by professional historians. The real problem with whiggish history of science is that it always aligns its value-judgements with the current orthodoxy. This is a problem especially if you happen to 
consider the current orthodoxy as wrong or unjust, ${ }^{15}$ but even if that is not the case there are good grounds for not signing up to whiggism. As Kuhn stressed, normal scientists actively select and reshape history so as to make their own paradigm appear to be the natural culmination of progressive developments. If historians of science would then jump in and produce more of that kind of history, there is a sense of futility to that enterprise. Why should we professional historians duplicate what scientists can and will do themselves (even if they tend to do it only after retirement)? We have all seen this sort of history, sometimes distilled into little boxes in science textbooks, and we rightly reject it as a model for professional history of science. But the reason for rejection is not that such history is wrong (it often is not so wrong), but that it is unoriginal and uninteresting. The dominant forces in society already remember history so as to suit themselves; we do not need professional historians to add to that work.

For the benefit of the wider society, I think it is far more interesting and useful if we professional historians give attention to the valuable bits of past science that modern scientists consider unimportant, outdated, or simply wrong. Much more stimulating accounts can be produced on the basis of a pluralist presumption: the current dominant system in a field of science is not the only good approach to the understanding of nature, and looking at the past is one of the possible ways of finding other good ones. What I like to practice is "loser's history", whose aim is to dig up from the past something good that has become neglected, and to bring it to the present.

But we cannot possibly pay attention to all the losers from the past! There are far too many, and many of them were real "losers" (in the American colloquial sense of the word) who do not deserve much attention. Now, that is a presentist judgement. When I say that some bits of past science are valuable enough to write about and others are not, I am making a judgement very much rooted in my present. And what is operative here is my present, not the present of the orthodox professional scientists. So Gordin $(2014,422)$ is not quite correct when he says that my kind of work is ultimately whiggish because my scientific judgements can only be made on the basis of present-day science. True, I cannot reject the entirety of modern science and still function in a sensible way intellectually in today's world (and nor can he), but I can go really quite far in hacking away a large part of the platform on which I stand.

So, while not pretending to get away from the inevitable level of presentism, we should indeed try to get away from whiggism, in most circumstances. In Section 3.1 I have indicated that even whiggism can serve the purpose of pluralism, but that is only in peculiar situations. Historians of science should make it at least part of our business to present accounts of past science that go against the grain of the dominant assumptions and analytical frameworks possessed by current scientists. As the saying goes, science is too important to be left entirely to the scientists. But I must stress that I have no anti-science agenda. Rather, the point is to save science from some of its own excesses. Gordin $(2014,421)$ is correct to call me an "anti-anti-Whig" in some of my methodological discourse. ${ }^{16}$ However, most of my historical practice is actually consciously anti-whiggish, yet presentist.

\footnotetext{
15 In that case anti-whiggish presentist historiography becomes a tool of resistance, as with emancipatory history. As Butterfield (1951, 171-172) once said in relation to the misuse of history by political powers: "We must teach history... precisely because so much bad history exists in the world already.... and even those who do not pretend to know any history... are the slaves of unconscious assumptions or concealed perversities on the subject of the past."

${ }^{16}$ He draws a parallel to the way in which many sensible people during the McCarthy era were "anti-anticommunist" while their sympathies were clearly not communist.
} 


\subsection{Complementary Science}

The pluralist historiography that I advocate here is closely related to my vision of the history and philosophy of science as "complementary science" (Chang 2004, ch. 6). The basic idea of complementary science is that we can do history and philosophy of science with the aim of improving scientific knowledge in ways that are not taken up by scientists themselves. In the context of this paper, it is important to note that what I am talking about is the improvement of present scientific knowledge, so we are squarely in the realm of presentist historiography. Given the current monistic and hegemonic tendencies in science, scientific progress tends to be accompanied by the shutting down of alternative paths of inquiry and a resulting loss of potential and actual knowledge. A critical and sympathetic engagement with the past of science allows us to recover the lost paths, which can also suggest new paths. In that way, methods and resources of history and philosophy of science can be employed in order to locate and address scientific questions productively. Complementary science seeks to generate scientific knowledge in places where science itself fails to do so.

This is not to deny that science is very good at what it does, but just to note that there are things that science does not currently do, even though they are quite scientific. The more well-defined and focused specialist science becomes, the more exclusive and exclusionary it tends to turn. This is another lasting insight from Kuhn's (1962) reflections on the nature of paradigm-based "normal science". A need for complementary science arises from the fact that specialist science cannot afford to be completely open. ${ }^{17}$ There are two chief aspects to this lack of openness. First, in specialist science many elements of knowledge must be taken for granted, since they are used as foundations or tools for studying other things. Then, certain other ideas and questions must be suppressed if they contradict or destabilize the taken-for-granted items of knowledge—not maliciously or gratuitously, but out of necessity. Second, not all worthwhile questions can be addressed, if only due to the limitation of resources. Each specialist scientific community will have some degree of consensus within itself about which problems are most urgent, and which problems can most plausibly be solved. Those problems that are considered either unimportant or unsolvable will be neglected. These are reasonable acts of prioritization. All the same, we must face up to the fact that suppressed and neglected questions do represent a loss of knowledge, actual and potential. What complementary science primarily aims at is not "the science of science", nor the understanding of past scientists. Complementary science, working alongside specialist science, aspires to enhance our knowledge and understanding of nature.

There are three main ways in which complementary science can generate and improve scientific knowledge. It can address critical questions concerning present science, recover useful ideas and facts from past science, and explore alternative conceptual systems and lines of experimental inquiry for future science. These ideas are explained in detail elsewhere, ${ }^{18}$ but I would like to revisit them here, giving very brief summaries and adding explanations of the connection to pluralist historiography.

\footnotetext{
17 Here and elsewhere I speak of "specialist science" rather than "normal science", so as not to distract those who reject Kuhn's particular ideas about normal science or paradigms.

18 See Chang (2004, 240-247). There is also a more brief discussion in Chang (2017), with some examples that I did not have available at the time of the earlier work.
} 


\subsection{Critical Awareness}

There is a sense in which we do not truly know anything unless we know how we know it. With a critical awareness of uncertainty and inconclusiveness, our knowledge reaches a higher level of flexibility and sophistication. For example, there is little that deserves the name of knowledge in being able to recite that the earth revolves around the sun. More intellectual value comes with the understanding of the evidence and arguments that convinced Copernicus and his followers to reject the firmly established, highly developed and eminently sensible system of geocentric astronomy established by Ptolemy. This is exactly the kind of scientific knowledge that is not easily available in current specialist science (who really knows about Ptolemaic astronomy any more?) but can be given by complementary science.

Now, critique may be considered the proper province of philosophy rather than history, but history really is one of the most effective tools for generating critical awareness. As Loison $(2016,36)$ puts it: "by reactivating the complexity of the past, one develops the tools to criticize present science." This plays out most importantly in relation to the contingency of scientific knowledge. ${ }^{19}$ If we know that there are credible alternatives to our current way of thinking, the latter will lose its appearance of invincibility and necessary truth. But first we have to be exposed to the possibility of alternatives, and history can help us here. Especially in the usual state of indoctrination in low-level modern science that is imposed on most educated people in today's Western and Western-oriented societies, our imagination is severely hampered and we are incapable of thinking in very different ways even if we try. As the right kind of foreign travel can expose and challenge our unrecognized cultural assumptions, our minds can be opened up by a liberal study of past science.

In my career as a historian of science, I have delighted in numerous knee-slapping moments when, reading some past scientific book or paper, I could not help exclaiming: "So, you could think like that!" It is impossible to give an exhaustive list, but just for a flavour: Celsius's original thermometer with an "upside-down" scale, 0 at boiling and 100 at freezing; Rumford's hypothesis of "frigorific rays" to explain the curious experiments in which a distant cold object cooled down a hot object instantly; Carnot's original understanding of heat engines as the production of work by caloric falling from a place of high temperature to low, in a waterfall analogy; Le Sage's explanation of gravity by reference to the pressure exerted by all-pervasive "ultramundane" particles bombarding everything from all directions; the surprisingly cogent phlogistonist explanation of what we now call redox reactions. ${ }^{20}$ These moments of recognizing new cogent conceptual possibilities from the past generate a profound sense of critical awareness.

Pluralist historiography can also give us critical awareness in a somewhat different way. Even if we are simply tracing the origins of today's orthodoxy, history can often reveal the contingency of the past decisions. In this sense, reading Kuhn on The Copernican Revolution (1957) is better philosophical education than reading The Structure of Scientific Revolutions (1962). How amazing it is to see that Copernicus did not have knock-down factual arguments against Ptolemy at the time! The recognition of contingency can lead to a sense of liberty and choice. This function of history in enhancing critical awareness is closely related to emancipatory presentism discussed in Section 3.3.

\footnotetext{
19 For an up-to-date and broad-ranging discussion of the contingency question, see Soler et al. (2015).

${ }^{20}$ I have written in detail about most of these episodes in Chang (2002), Chang (2004), and Chang (2012a).
} 


\subsection{Recovery}

In the line of work that I call "recovery" under the scheme of complementary science, the historian adds to scientific knowledge by dredging up forgotten facts and ideas from past science. Again, the main aim here is presentist: reviving past knowledge to let it live in the present. Even the old-fashioned historian's connoisseurship of the past is really an act of recovery, into which we can inject a more active and conscious presentism. ${ }^{21}$ Now, it is important to recognize that those who appreciate recovery must subscribe to pluralism at least to a degree, to believe that there can be something worth recovering in the parts of the past that we have discarded. Such pluralism is usually not extended to the realm of science, where the common sense is that what scientists have discarded must be either wrong or useless.

Ultimately, the possibility of useful recovery can only be demonstrated by its actuality. This is more easily done with experiments than theory. For example, in my work on the history of temperature, I came across many puzzling experimental reports of anomalous boiling temperature and behavior of water even under standard conditions (Chang 2004, ch. 1). I was able to confirm most of these observations with my own simple experiments (Chang 2007; 2011, Sect. 3). Since that experience I have been engaged in a steady line of laboratory work recovering a number of lost phenomena, especially in the area of electrochemistry (for early reports, see Chang 2011, Sects. 4, 5 and Chang 2017). My experiments are "physical" rather than "historical" replications (Chang 2011, 320). That is to say, my primary aim in these experiments is to recover the phenomena in question, rather than to recreate the exact conditions of the past experiments or the personal experiences of the past experimenters. It is fine to use modern apparatus and materials; in fact, the less similar the specific circumstances, the better for showing the robustness of the phenomena. ${ }^{22}$ This is presentism again: in this line of work my learning about the past of science adds to our present knowledge of nature.

Recovery is not restricted to facts, but extends to ideas as well. Come to think of it, historians of science have always made efforts to recover all sorts of ideas that modern science has forgotten. There is no point in picking out a few examples out of the great multitude, but the works of William Newman and Lawrence Principe on the history of alchemy deserve a special mention, as they have forged a rare and exemplary path of conceptualand-factual recovery in an area of science that is normally not even considered scientific. ${ }^{23}$ In my own work there are also many examples, often linked to the cases cited above in which historical learning has led to critical awareness.

\subsection{Extension}

Recovery and critical awareness are valuable in themselves, but they can also stimulate the production of genuinely novel knowledge. The work of extension is strictly speaking

\footnotetext{
21 Beautiful expressions of this point were given by Henri-Irénée Marrou and Barthold Niebuhr, quoted in Chang $(2017,100)$.

22 What is involved here is an indirect demonstration (rather than an assumption) of the constancy of nature, which underlies what Loison (2016, 30-31) calls "empirical presentism".

23 Their contributions have been published in a number of different places, but Fors et al. (2016) gives a good sense of this line of work, with Principe's main publications listed in footnote 6 on p. 87 . A good indication of Newman's work can be seen in his online resource on Newton's alchemy (Newman 2019).
} 
not historical, but it is a direct consequence and benefit of doing history in the presentist and pluralist way I have been advocating here. Again, it will strike many readers as highly implausible that genuinely novel scientific knowledge can stem from historical work, and ultimately the only way to demonstrate the possibility is to show actual successes.

For example, it was through his study of the history of mechanics that Ernst Mach recognized Newton's absolute space and time to be unnecessary. This recognition then prompted Mach to advocate a relational theory of space, which in turn helped pave Einstein's path to relativity (see Norton 2010). Mach's "historical-critical method" was intended to lead to new and better science through a critical examination of the past. In our own day, Martin Rudwick took methodological ideas from Cuvier to help him in "reconstructing the mode of life of extinct invertebrates, of brachiopods", which was successful despite "hostility and opposition from paleontologists who could not think that anything good could come from someone pre-Darwin, especially an anti-evolutionist whom [he] was using for evolutionary purposes." ${ }^{24}$ Such productive engagements with the past of science cannot be undertaken without a pluralist allowance that the dominant science of one's own day is not the only possible way of understanding nature. Loison $(2016,36)$ stresses this as a requirement for his "critical presentism": in Canguilhem's idiom, "the truth of the day" is not "the truth of always".

As with recovery, it is easier in the realm of experimental work to convince skeptical observers of the plausibility of extension. When a forgotten experiment is re-discovered and replicated, follow-up questions arise very naturally. Theoretically, how do we explain the recovered phenomena? For example, when I recovered Charles Sylvester's experiment of growing a beautiful silver tree by simply inserting a copper wire into a solution of silver nitrate (Chang 2017, 99-101), questions immediately arose as to the cogency of Sylvester's 200-year-old explanation. And if we reject Sylvester's own explanation, what would be a better one ${ }^{25}$ Experimentally, once any interesting experiment has been made, plans for further experiments are likely to arise immediately: "but what happens if I do this?" And new experiments are quite likely to reveal new facts. For example, in the course of doing some follow-up experiments reproducing basic early 19th-century voltaic cells, I was led to discover that the electrolysis of a solution of common salt $(\mathrm{NaCl})$ results in the solution of gold wire that is used as the positive-side electrode (anode), when the applied voltage is in a window of roughly 2 to 3.5 volts (Chang 2017, 103).

Historians have generally refrained from further developing the knowledge that they uncover from past science, but I see no compelling reasons for this. An emblematic example here is Kuhn. Having made such strenuous and persuasive arguments that certain discarded systems of knowledge (e.g. Aristotelian physics, Ptolemaic astronomy, or the phlogiston theory) were coherent and not simply incorrect, Kuhn gave no indication that these theories deserved to be developed further from where they were at the time of their extinction. Why not? According to his criterion of judgement, scientific revolutions constitute progress when the newer paradigm acquires a greater problem-solving ability than ever achieved by the older paradigm. But how do we know that the demonstrated superiority of the new paradigm is not merely a result of the fact that scientists abandoned the older paradigm and gave up the effort to improve its problem-solving ability?

\footnotetext{
24 See Meyer (2008) for this quotation and a brief introductory discussion.

${ }^{25}$ I have not yet managed to get many current specialists in electrochemistry to take up these questions seriously, but that is not to say such questions cannot form useful research topics for current specialists.
} 
A similar question also arises at the conclusion of some other historians' works on scientific controversy. For example, Steven Shapin and Simon Schaffer (1985) strongly challenged the received wisdom that Hobbes's ideas about pneumatics were rightly rejected in favor of Boyle's superior views. But they did not suggest that it would be worthwhile to try developing Hobbes's ideas further. Ordinary historians, of course, have an easy answer here: it is not their job to develop scientific ideas actively. But whose job is it? It is perfectly understandable that scientists would not want to be drawn into research programmes rejected long ago. This is where complementary science enters. Lacking an obligation to conform to the current orthodoxy, the complementary scientist is free to invest some time and energy in developing unorthodox systems.

\section{Concluding Remarks}

The purpose of historiography is usually seen as the description and explanation of the past. What I have proposed in this paper is that history-writing can and should serve the purpose of improving the present as well. This suggestion may not be so controversial in general, but it is usually met with incredulity and suspicion when it is carried into the realm of science. This is because of the strong monist intuitions people have about science. When combined with the kind of progressivism that is at the basis of whiggism, this monism confers an aura of inevitability to our current scientific knowledge.

Pluralist historiography can help break down this illusion, and thereby actively aid scientific progress, conceived in a broad-minded way that encompasses various aims that earnest seekers of knowledge may have. Empirical facts and theoretical ideas recovered from the past can be incorporated into our store of knowledge, and they can also stimulate present scientific inquiry. Thereby history can actually take us on to the roads-not-taken that constitute potential directions for new scientific developments. Even just critical scrutiny can help the progress of science. By exposing unrecognized biases and assumptions in present science inherited from the past without fresh critical examination, historical work can encourage a helpful re-evaluation and re-orientation of present research-factually, theoretically, and methodologically.

More broadly, pluralist historiography can help us revise our very conception of progress, by raising important questions about what should count as progress. One lasting lesson from Kuhn is pertinent: scientists working in different paradigms have different aims and different values. And part of the work here, recognized so clearly by historians of science now, is highlighting ethical and social implications of scientific work, and recalling valuable connections between science and other human endeavors. I have largely neglected the broader social dimensions of science in this paper, but the relevance of history to these dimensions will be more easily accepted than the role of history in relation to the more strictly epistemological dimensions of science, which is what I have addressed here.

I think we have an exciting new prospect here: historical work can facilitate scientific progress itself, going clearly beyond the task of merely describing and explaining the progress that has happened without its influence. This is not such a strange idea after all, in relation to the role of history in other realms of human life. Actually what is strange is the notion that scientific progress can somehow be made without a proper and insightful understanding of the past. 
Acknowledgements I thank Matteo Vagelli, Laurent Loison, Iván Moya Diez, and Jean-François Braunstein for welcoming me to the Journée d'études on "Epistémologie historique et les deesunités des sciences" in Paris in May 2018, and for inviting me to contribute to this special issue. In addition, I would like to thank my hosts and audiences at other places where I presented earlier versions of this material: Department of History, Princeton University (especially Jenny Rampling and Angela Creager); the AIP Early Career Conference for Historians in the Physical Sciences, San Sebastian (especially Greg Good and Jaume Navarro); and the Max Planck Institute for History of Science, Berlin. Similarly, I have benefited from giving various related presentations at the following occasions: inaugural lectures at University College London and the University of Cambridge; the International Congress of the History of Science, Technology and Medicine in Manchester in 2013, the prize lecture for the 2013 Fernando Gil International Prize for the Philosophy of Science in Lisbon, and the Wilkins-Bernal-Medawar Lecture at the Royal Society of London in 2016. I would also like to thank two anonymous referees for the JGPS for helpful and detailed suggestions.

Open Access This article is licensed under a Creative Commons Attribution 4.0 International License, which permits use, sharing, adaptation, distribution and reproduction in any medium or format, as long as you give appropriate credit to the original author(s) and the source, provide a link to the Creative Commons licence, and indicate if changes were made. The images or other third party material in this article are included in the article's Creative Commons licence, unless indicated otherwise in a credit line to the material. If material is not included in the article's Creative Commons licence and your intended use is not permitted by statutory regulation or exceeds the permitted use, you will need to obtain permission directly from the copyright holder. To view a copy of this licence, visit http://creativecommons.org/licenses/by/4.0/.

\section{References}

Arabatzis, T. (2019). Explaining science historically. Isis, 110, 354-359.

Biagioli, M. (1993). Galileo, courtier: The practice of science in the culture of absolutism. Chicago: University of Chicago Press.

Butterfield, H. (1931). The Whig interpretation of history. London: G. Bell.

Butterfield, H. (1951). History and human relations. London: Collins.

Chang, H. (1993). A misunderstood rebellion: The twin-paradox controversy and Herbert Dingle's vision of science. Studies in History and Philosophy of Science, 24, 741-790.

Chang, H. (2002). Rumford and the reflection of radiant cold: Historical reflections and metaphysical reflexes. Physics in Perspective, 4, 127-169.

Chang, H. (2004). Inventing temperature: Measurement and scientific progress. New York: Oxford University Press.

Chang, H. (2007). The myth of the boiling point (online paper with video links), http://www.sites.hps.cam. ac.uk/boiling/. Initially posted on the website of University College London on 18 Oct 2007. Accessed 9 May 2020.

Chang, H. (2009). We have never been whiggish (about phlogiston). Centaurus, 51, 239-264.

Chang, H. (2011). How historical experiments can improve scientific knowledge and science education: The cases of boiling water and electrochemistry. Science and Education, 20, 317-341.

Chang, H. (2012a). Is water $\mathrm{H}_{2} \mathrm{O}$ ? Evidence, realism and pluralism. Dordrecht: Springer.

Chang, H. (2012b). Beyond case-studies: History as philosophy. In S. Mauskopf \& T. Schmaltz (Eds.), Integrating history and philosophy of science (pp. 109-124). Dordrecht: Springer.

Chang, H. (2017). Who cares about the history of science? Notes and Records: The Royal Society Journal of the History of Science, 71, 91-107.

Cohen, H. F. (Ed.) (2019). Focus: Explanation in the history of science. Isis, 110, 290-359.

Croce, B. (1941). History as the story of liberty, trans. Sylvia Sprigge. New York: Norton.

Cushing, J. T. (1994). Quantum mechanics: Historical contingency and the Copenhagen hegemony. Chicago: University of Chicago Press.

Forman, P. (1971). Weimar culture, causality, and quantum theory, 1918-1927: Adaptation by German physicists and mathematicians to a hostile intellectual environment. Historical Studies in the Physical Sciences, 3, 1-115.

Forman, P. (1991). Independence, not transcendence, for the historian of science. Isis, 82, 71-85.

Fors, H., Principe, L. M., \& Sibum, H. O. (2016). From the library to the laboratory and back again: Experiment as a tool for historians of science. Ambix, 63, 85-97. 
Gellner, E. (1988). Plough, sword and book: The structure of human history. Chicago: University of Chicago Press.

Gordin, M. (2014). The Tory interpretation of history. Historical Studies in the Natural Sciences, 44, 413-423.

Heilbron, J. L. (1985). The earliest missionaries of the Copenhagen spirit. Revue d'Histoire des Sciences, $38,195-230$.

Jardine, N. (2003). Whigs and stories: Herbert Butterfield and the historiography of science. History of Science, $41,125-140$.

Kuhn, T. S. (1957). The Copernican Revolution: Planetary astronomy in the development of Western thought. Cambridge: Harvard University Press.

Kuhn, T. S. (1962). The structure of scientific revolutions. Chicago: University of Chicago Press.

Kuhn, T. S. (1971). Notes on Lakatos. In R. C. Buck \& R. S. Cohen (Eds.), PSA 1970: In memory of Rudolf Carnap (pp. 137-146). Dordrecht: Reidel.

Kuhn, T. S. ([1968] 1977). The history of science. In T. S. Kuhn, The essential tension (pp. 105-126). Chicago: University of Chicago Press.

Kuhn, T. S. (1980). The halt and the blind: Philosophy and history of science (review of C. Howson, ed., Method and appraisal in the physical sciences). British Journal for the Philosophy of Science, 31, $181-192$.

Kuhn, T. S., Heilbron, J. L., Forman, P., \& Allen, L. (1967). Sources for history of quantum physics: An inventory and report. Philadelphia: American Philosophical Society.

Lakatos, I. (1971). History of science and its rational reconstructions. In R. C. Buck \& R. S. Cohen (Eds.), PSA 1970: In memory of Rudolf Carnap (pp. 91-136). Dordrecht: Reidel.

Loison, L. (2016). Forms of presentism in the history of science: Rethinking the project of historical epistemology. Studies in History and Philosophy of Science, 60, 29-37.

Meyer, M. (2008). Bringing history to science and science to history: Martin Rudwick wins Sarton Medal. HSS Newsletter, 37(2), 14-15. http://hssonline.org/wp-content/uploads/2015/01/Newsletter2008-April .pdf. Accessed 9 May 2020.

Newman, W. R. (2019). The chymistry of Isaac Newton. http://webapp1.dlib.indiana.edu/newton/. Accessed 9 May 2020.

Norton, J. D. (2010). How Hume and Mach helped Einstein find special relativity. In M. Domski \& M. Dickson (Eds.), Discourse on a new method: Reinvigorating the marriage of history and philosophy of science (pp. 359-386). Chicago and La Salle: Open Court.

Pickering, A. (1984). Constructing quarks: A sociological history of particle physics. Chicago: University of Chicago Press.

Shapin, S. (1975). Phrenological knowledge and the social structure of early nineteenth-century Edinburgh. Annals of Science, 32(3), 219-243.

Shapin, S., \& Schaffer, S. (1985). Leviathan and the air-pump: Hobbes, Boyle, and the experimental life. Princeton: Princeton University Press.

Soler, L., Trizio, E., \& Pickering, A. (Eds.). (2015). Science as it could have been: Discussing the contingency/inevitability problem. Pittsburgh: University of Pittsburgh Press.

Wilson, A., \& Ashplant, T. G. (1988). Whig history and present-centred history. The Historical Journal, $31(1), 1-16$.

Publisher's Note Springer Nature remains neutral with regard to jurisdictional claims in published maps and institutional affiliations. 